medenicaluka@yahoo.com

\title{
УТИЦАЈ ИНПУТА НА ПРАВОПИСНА ПОСТИГНУЋА СТУДЕНАТА РУСКОГ ЈЕЗИКА ФИЛОЛОШКОГ ПРОФИЛА
}

АПСТРАКТ: Истраживања које се баве утицајем инпута на ученичка и студентска постигнућа у контексту страних језика веома су актуелна у свету, док, по нашем мишљењу, у Србији наведено питање није истражено у довољној мери. Стога је предмет овог рада утврђивање чинилаца који утичу на правописна постигнућа студената руског језика. Истраживањем су обухваћена тридесет три испитаника, студената треће године Филолошког факултета Универзитета у Београду. Како бисмо утврдили да ли фактор инпута утиче на повећање правописних постигнућа, студенте смо груписали према нивоу претходне изложености језику и према постигнућима на иницијалном тестирању, а затим их поделили на експерименталну и контролну групу. Резултати иницијалног и финалног тестирања били су подвргнути поређењу како би се открило у којој мери је фактор инпута утицао на правописна постигнућа студената. Дошли смо до закључка да повећање ваннаставног инпута утиче на правописна постигнућа испитаника, као и да је инпут у периоду до иницијалног тестирања био прецизан предиктор студентских постигнућа.

Кључне речи: инпут, руски језик као страни, правописна постигнућа, Филолошки факултет.

\section{THE INFLUENCE OF INPUT ON ORTHOGRAPHIC ACHIEVEMENT OF PHILOLOGY STUDENTS OF THE RUSSIAN LANGUAGE}

ABSTRACT: Studies dealing with the effects of input on second language learning achievements in both school and academic contexts attract considerable interest in many countries. However, in our opinion, the area has not been researched to its full potential in Serbia. Thus, this paper sets out to discover factors that influence the orthographic achievements of Russian language students. A total of thirty-three respondents took part in this research and they were all third-year students of the Faculty of Philology at the University of Belgrade. In an attempt to examine input as a factor that can improve students' orthographic achievements, we formed two student groups - the experimental and the control group, on the basis of their previous exposure to L2 and their results on the initial assessment test. The initial and final testing results were compared to evaluate the role of the input factor in students' orthographic achievements. Our work further suggests that extended exposure to extracurricular input impacts the orthographic achievement of respondents. Finally, our result has led us to conclude that input in the period preceding the initial testing offered compelling signals for predicting students' achievement.

Key words: input, Russian as a foreign language, orthographic achievement, Faculty of Philology. 


\section{1. УВОД}

Питање инпута у настави језика веома је актуелно, јер је усвајање језика без одговарајућег инпута немогуће (Gass 1997). Под инпутом се у усвајању језика подразумева објективан и физички мерљив садржај којем је особа изложена аудитивно или визуелно (Carroll 1999: 341), тј. инпут који је доступан приликом усвајања другог језика представља сирове језичке податке из којих се изводе правила и структура циљног језика (Chaudron 1985: 3).

Хипотеза о разумљивом инпуту (Krashen 1985) изузетно је утицајна у теорији усвајања страног језика и након више од четири деценије. Крешен истиче значај оптималног инпута и подвлачи да особа усваја језик једино када разуме садржај инпута. У својим каснијим радовима аутор наводи и низ истраживања у којима доказује позитиван утицај читања литературе коју ученик сам одабере на постигнућа у усвајању страног језика, укључујући утицај на вокабулар, граматику, писмено изражавање, разумевање прочитаног и правопис (Krashen 2004, Krashen, Lee, \& Lao 2017, Renandya, Jacobs, Krashen, \& Ong 2019). Елис (Ellis 1994: 53) такође истиче да читање пружа идеално окружење за имплицитно усвајање правописа страног језика.

У Србији су слична истраживања у контексту страних језика веома ретка. Стипанчевић (Stipančević 2020) је у једном од скоријих истраживања испитивала утицај екстензивног читања и слушања у настави немачког језика код студената који уче језик као изборни, на нивоу А2. Ауторка долази до сазнања да инпут није утицао на повећање рецептивних вештина, али јесте на повећање продуктивних вештина. У истраживању је експериментална група показала боље резултате у писменом изражавању, док су постигнућа студената у разумевању прочитаног и разумевању говора била на истом нивоу као и код контролне групе.

Према нашем сазнању до сада нису спровођена истраживања која мере утицај инпута у настави правописа руског језика у Србији, те ћемо у овом раду покушати да утврдимо да ли испитивани чиниоци имају утицај на правописна постигнућа студената Филолошког факултета.

\section{2. ЦИЉ ИСТРАЖИВАЬА И ХИПОТЕЗА}

Приликом уписа на Филолошки факултет Универзитета у Београду студенти имају могућност да одаберу један од четири студијска програма. У оквиру програма Језик, књижевност, култура (у даљем тексту ЈКК) студенти 
се могу уписати на одговарајући профил. Поред нешто више од двадесет страних језика студијски програм ЈКК нуди и руски језик као главни. У оквиру профила постоји низ обавезних предмета ${ }^{1}$, међу којима је и предмет Савремени руски језик Г-5, у петом семестру. Иако се на Филолошки факултет у Београду могу уписати и матуранти који нису учили руски језик, очекује се да до треће године студија студенти владају језиком на доста високом нивоу. Како се наставни циљеви филолошких студија разликују од курсева стандардног језика или језика струке, једна од компоненти у оквиру предмета Савремени руски језик $\Gamma-5$ јесте Правопис рускога језика. Наведена вежбања студенти похађају од прве године студија, а у оквиру вежби из правописа од студената се очекује да овладају одређеним правописним правилима и да их примењују у писменом изражавању. На трећој години студија сви студенти усвајају правила на руском језику у идентичним условима, а наставни инпут им је веома висок. На руском језику се одвија низ вежби: правописне вежбе у трајању од једног двочаса, граматичке у трајању од једног двочаса, лексичке вежбе у трајању од два двочаса и говорне вежбе у трајању од једног двочаса. На тај начин наставни инпут на вежбама на недељном нивоу износи чак десет двочаса на трећој години студија. Поред тога, одређени број предавања се такође одвија на руском језику. Потребно је напоменути да је и обавезна литература за поједине предмете на руском језику. Дакле, наставни инпут је код свих студената једнак. Студенте који нередовно похађају наставу у истраживању посебно разматрамо како бисмо избегли неуједначен наставни инпут. Редовност похађања наставе често јесте један од предиктора постигнућа, међутим, чак и када узимамо у обзир наведени фактор увиђамо да одређени студенти ипак постижу боље резултате на испитима од других колега. До сада није истраживано који чиниоци утичу на повећања постигнућа студената русистике, стога је циљ нашег истраживања да утврдимо да ли фактори које испитујемо имају утицај на правописна постигнућа студената треће године Филолошког факултета Универзитета у Београду.

На основу свега изложеног постављамо хипотезу да повећање инпута утиче на правописна постигнућа студената. Дакле, у раду ћемо покушати да

\footnotetext{
${ }^{1} \mathrm{O}$ анализи изборних и обавезних предмета и наставних програма, као и о положају русистике на Филолошком факултету Универзитета у Београду пише Гинић (Гинич, Айджанович, \& Меденица 2020).
} 
установимо да ли повећање ваннаставног инпута кроз читање и/или аудиокњиге утиче на правописна постигнућа.

\section{3. ТЕХНИКЕ, ИНСТРУМЕНТИ И УЗОРАК}

У циљу прикупљања података о инпуту испитаника до иницијалног тестирања коришћена је техника анкетирања. За потребе рада осмишљен је и дизајниран упитник који су попуњавали студенти треће године русистике на дан иницијалног тестирања. Упитник је био подељен у два дела. Први део односио се на инпут до уписа на Филолошки факултет, а други део се односио на инпут у току прве и друге године студија. Тако су се студенти изјашњавали у којој мери су били аудитивно или визуелно изложени руском језику, тј. да ли су из забаве читали књиге на руском језику како пре уписа на факултет тако и на првој и другој години студија, да ли су читали на руском језику обавезну литературу на првој и другој години студија, да ли су читали штампу, форуме и друге онлајн садржаје, као и да ли су гледали филмове, серије и слушали музику на руском језику у истом периоду. Поред тога, упитник је садржао основне податке о студенту: име и презиме, узраст на дан попуњавања анкете и узраст у ком је особа почела да учи руски језик. Иницијално тестирање спроведено је 27. новембра 2020. године.

У циљу прикупљања података о инпуту испитаника у периоду од иницијалног до финалног тестирања коришћен је наменски дневник који су водили студенти у периоду од четири недеље, од краја новембра до 25. децембра 2020. године, када је спроведено финално тестирање. Студенти су уписивали називе књига које су читали или слушали (аудио-књиге) у том периоду. Како се у оквиру правописних вежби на Филолошком факултету у настави користи електронска платформа Myдл (Moodle), студенти су имали могућност да у оквиру специјално креиране активности добију препоруке за читање. Ова могућност је била дата како би се избегао одабир искључиво обавезне литературе за предмете из књижевности, већ се мерио и утицај инпута из књига које су студенти из забаве читали и/или слушали. Осим тога, на поменутом списку налазиле су се и књиге које су по нашој процени нешто једноставније од дела Гогоља, Љермонтова, Пушкина и других руских класика које студенти читају на другој и трећој години студија. Хју и Нејшн (Hu \& Nation 2000) испитивали су однос између броја непознатих речи у тексту и постигнућа у разумевању прочитаног у енглеском као страном језику. Аутори су закључили да 90\% покривености текста не даје добре резултате у разумевању прочитаног, јер је изузетно мали број испитаника 
постигао адекватно разумевање, док је код 95\% покривености текста нешто већи број испитаника постигао адекватно разумевање текста, али према ауторима тај број испитаника није био задовољавајући. Због тога аутори препоручују да број познатих речи у тексту мора бити чак 98\%. Имајући ово у виду, било нам је нарочито важно да се на списку који је понуђен студентима нађу и књиге које ће бити разумљиве и оним студентима који још увек нису у могућности да читају руске класике на руском језику, већ то чине на српском, због великог броја непознатих речи у оригиналним делима.

Како нам је циљ био да одредимо правописна постигнућа студената, сматрали смо да диктат представља ефикасан мерни инструмент, те су подаци о постигнућима студената мерени уз помоћ диктата. Можемо сматрати да је инструмент поуздан јер су писању диктата студенти приступили у истим условима и истога дана. Имајући у виду да је и иницијални и финални диктат садржао 186 речи, можемо сматрати да је инструмент дискриминативан и да пружа добар увид у разлике у постигнућима студената.

Истраживањем су обухваћена тридесет три испитаника, студената треће године Филолошког факултета Универзитета у Београду.

\section{4. РЕЗУЛТАТИ ИСТРАЖИВАЬА}

Након детаљне анализе иницијалних резултата постигнућа студената и података из упитника сматрали смо да би било сврсисходно студенте поделити у три групе, према постигнућима.

\section{1. Прва група}

Прву групу чини четрнаест студената. У питању су студенти који су на иницијалном диктату имали између 94,6\% и 100\% успешности (просечно 96,6\% успешности), тј. имали су виша постигнућа од својих колега из друге и треће групе. Интересантно је да су се сви студенти прве групе у анкети изјаснили за одговор да имају скоро свакодневни инпут у периоду од најмање годину дана. Период трајања интензивног инпута био је у корелацији са узрастом у ком је испитаник почео да учи језик. У првој групи имамо једног студента који је почео да учи језик од рођења, шесторо студената који су почели да уче језик у петом разреду основне школе и чак седморо студената који су се по први пут сусрели са језиком тек на факултету. Уколико детаљније сагледамо инпут студената на првој и другој години студија, уочићемо да је он шаренолик. Међутим, код сваког испитаника прве групе, макар у једној (код 14\% испитаника), а чешће у 
две или више категорија од укупно четири бележимо скоро свакодневни инпут. Тако је 57\% студената скоро свакодневно читало лектиру из књижевности и/или обавезну литературу на руском језику на првој и другој години студија. Чак 71\% испитаника изјаснило се да је скоро свакодневно читало штампу, форуме и друге онлајн садржаје на руском језику у истом периоду. Исти проценат испитаника изјаснио се да је скоро свакодневно гледао руске серије, филмове и/или слушао руску музику. Нажалост, 50\% испитаника уопште није читало из забаве књиге на руском језику, док остали то нису радили скоро свакодневно, већ у току лета или неколико пута годишње.

У периоду од иницијалног до финалног диктата ова група студената наставила је са скоро свакодневним инпутом и њихови резултати су се у просеку повећали са 96,6\% успешности на 97,4\% успешности. То се може сматрати веома задовољавајућим, имајући у виду да су иницијална постигнућа била на изузетно високом нивоу. На основу детаљне анализе постигнућа и анкете испитаника прве групе дошли смо до закључка да су, без обзира на врсту инпута, правописна постигнућа изузетно висока код оних студената који имају скоро свакодневни инпут у дужем периоду, али да је конкретни инструмент тестирања недовољно дискриминативан за ову групу студената, јер су њихова постигнућа на иницијалном диктату била изразито висока, са просеком од чак 96,6\% успешности. И поред тога, можемо закључити како нам је прва група испитаника указала на чињеницу да је инпут прецизан предиктор постигнућа.

\section{2. Друга група}

Другу групу чини дванаест студената. У питању су испитаници који су имали нешто слабија постигнућа од прве групе, али ипак боља од треће групе испитаника - са просечних 91,8\% успешности на иницијалном диктату, а у распону од 89,2\% до 93,5\% успешности. У другој групи осморо студената је руски језик почело да учи на факултету, док је њих четворо почело да га учи у петом разреду основне школе. Оно што је заједничко овој групи испитаника, поред слабијих постигнућа у односу на прву групу, јесте чињеница да нико од испитаника у периоду пре иницијалног диктата није имао скоро свакодневни инпут у било којој од четири категорије. Дакле, и ова група студената, као и прва, чини хомогену групу по питању изложености руском језику ван факултета. И прву и другу групу чине студенти који редовно похађају наставу и редовно испуњавају своје додатне обавезе на вежбама из правописа на платформи Мудл (Moodle). Код друге групе, међутим, бележимо нижи ваннаставни инпут у односу на прву групу. Тако су обавезну литературу на првој и другој години 
студија испитаници друге групе у најбољем случају читали једном недељно (свега 25\%), док су остали то чинили ређе. Свега 16\% студената изјаснило се да је једном недељно читало штампу, форуме и друге онлајн садржаје на руском језику, док су остали испитаници то чинили још ређе. Идентично су се изјаснили и у вези са гледањем серија, филмова и слушањем музике на руском језику. Узимајући у обзир горе наведене податке о инпуту до иницијалног диктата, као и резултате иницијалног диктата, можемо сматрати да је у питању хомогена група студената која се може поделити на експерименталну и контролну групу.

Експерименталну групу чинили су студенти који су скоро свакодневно у периоду од четири недеље, од иницијалног до финалног диктата, били изложени инпуту. У питању је било четворо студената, чија су постигнућа на иницијалном диктату износила 90,8\% и који су у наведеном периоду скоро свакодневно читали и/или слушали аудио-књиге на руском језику. Испитаници су бирали књиге које им представљају обавезну литературу за испите из књижевности, али и књиге из области популарне психологије и стрипове. Један студент експерименталне групе почео је да учи руски језик у петом разреду основне школе, а осталих троје на факултету.

Осморо студената чинило је контролну групу, чија су постигнућа на иницијалном диктату била нешто већа од експерименталне групе и износила су $92,2 \%$ успешности. Ови испитаници нису повећали инпут у периоду од иницијалног до финалног диктата. Троје студената контролне групе почело је да учи руски језик у петом разреду основне школе, а њих петоро на факултету.

Резултати финалног диктата показали су да су студенти експерименталне групе остварили напредак од читавих 4,2\%, са просеком од 95\% успешности на финалном диктату. Контролна група је незнатно назадовала, за 0,9\%, и постигла резултат од 91,3\% успешности на финалном диктату. У Табели 1. можемо сагледати укупна постигнућа експерименталне и контролне групе.

\begin{tabular}{llllc}
\hline & $\begin{array}{l}\text { Број } \\
\text { студената }\end{array}$ & $\begin{array}{l}\text { Иницијална } \\
\text { постигнућа }\end{array}$ & $\begin{array}{l}\text { Финална } \\
\text { постигнућа }\end{array}$ & Разлика \\
\hline $\begin{array}{l}\text { Експериментална } \\
\text { група }\end{array}$ & 4 & $90,8 \%$ & $95 \%$ & $+4,2 \%$ \\
\hline Контролна група & 8 & $92,2 \%$ & $91,3 \%$ & $-0,9 \%$ \\
\hline
\end{tabular}

Табела 1. Укупна постигнућа експерименталне и контролне групе 
Назадовање студената контролне групе можемо објаснити и тиме да нису били у могућности да примењују правописна правила руског језика због слабе изложености језику, док је код експерименталне групе повећање инпута утицало, између осталог, и на боље разумевање, а самим тим и ефикаснију примену правописних правила.

У Табели 2. приказаћемо појединачна постигнућа свих студената друге групе, како експерименталне (ЕГ) тако и контролне групе (КГ).

\begin{tabular}{llll}
\hline & $\begin{array}{l}\text { Иницијална } \\
\text { постигнућа }\end{array}$ & Финална постигнућа & Разлика \\
\hline ЕГ1 & $89,2 \%$ & $96,2 \%$ & $+7 \%$ \\
\hline ЕГ2 & $89,2 \%$ & $94,6 \%$ & $+5,4 \%$ \\
\hline ЕГ3 & $92,4 \%$ & $95,1 \%$ & $+2,7 \%$ \\
\hline ЕГ4 & $92,4 \%$ & $94 \%$ & $+1,6 \%$ \\
\hline КГ1 & $93,5 \%$ & $93,5 \%$ & 0 \\
\hline КГ2 & $92,4 \%$ & $92,4 \%$ & 0 \\
\hline КГ3 & $93,5 \%$ & $92,4 \%$ & $-1,1 \%$ \\
\hline КГ4 & $92,4 \%$ & $89,7 \%$ & $-2,7 \%$ \\
\hline КГ5 & $89,2 \%$ & $87,6 \%$ & $-1,6 \%$ \\
\hline КГ6 & $91,9 \%$ & $89,2 \%$ & $-2,7 \%$ \\
\hline КГ7 & $91,3 \%$ & $90,8 \%$ & $-0,5 \%$ \\
\hline КГ8 & $93,5 \%$ & $94,6 \%$ & $+1,1 \%$ \\
\hline
\end{tabular}

Табела 2. Појединачна постигнућа студената

Можемо закључити да је истраживање у оквиру друге групе студената јасно указало да је фактор инпута значајно утицао на правописна постигнућа студената експерименталне групе.

\subsection{Tpeћa гpyna}

Трећу групу чини седам студената. У питању су испитаници који су имали најслабија постигнућа. Свега просечних 83,6\% успешности на иницијалном диктату, а у распону од 76,8\% до 88,7\% постигнућа. У трећој групи је један испитаник почео да учи руски језик у петом разреду основне школе, један у првом разреду гимназије, а њих петоро на факултету. Код ове групе испитаника, поред слабијих постигнућа на иницијалном диктату, заједничка је и нередовност испуњавања обавеза на платформи Мудл и нередовност похађања наставе (неки студенти су, рецимо, запослени). Због 
тога је било потребно ове студенте издвојити у трећу групу испитаника. Што се изложености језику ван факултета тиче, долазимо до закључка да је она веома слична изложености коју смо забележили код друге групе. Међутим, због ниског наставног инпута, а услед нередовности похађања наставе, ова група студената остварила је нижа постигнућа на иницијалном диктату. Можемо сматрати да и ова група студената чини једну хомогену целину по питању изложености језику, постигнућима и редовности, а по чему у потпуности одударају од прве групе. Од друге групе их, пак, разликује нередовност похађања наставе и постигнућа на иницијалном диктату, док им се ваннаставни инпут подудара.

Експерименталну групу у оквиру треће групе чинило је двоје испитаника који су скоро свакодневно били изложени инпуту у периоду од иницијалног до финалног диктата. Они су читали књиге са списка обавезне литературе за испите из књижевности, али и белетристику по свом избору. Оба испитаника почела су да уче руски језик на факултету. Петоро студената чинило је контролну групу. Ови испитаници нису променили своје навике и нису повећали инпут у том периоду. Резултати иницијалног и финалног диктата свих учесника приказани су у Табели 3 .

\begin{tabular}{lllll}
\hline & $\begin{array}{l}\text { Број } \\
\text { студената }\end{array}$ & $\begin{array}{l}\text { Иницијална } \\
\text { постигнућа }\end{array}$ & $\begin{array}{l}\text { Финална } \\
\text { постигнућа }\end{array}$ & Разлика \\
\hline $\begin{array}{l}\text { Експериментална } \\
\text { група }\end{array}$ & 2 & $80,9 \%$ & $87,3 \%$ & $+6,4 \%$ \\
\hline Контролна група & 5 & $84,6 \%$ & $84,4 \%$ & $-0,2 \%$ \\
\hline
\end{tabular}

Табела 3. Укупна постигнућа експерименталне и контролне групе

Студенти експерименталне групе су на иницијалном диктату постигли резултат од $80,9 \%$, а на финалном диктату резултат од $87,3 \%$ успешности, што значи да су остварили напредак од чак 6,4\%. Испитаници контролне групе назадовали су $0,2 \%$, јер су им резултати били $84,6 \%$ и $84,4 \%$ успешности. Можемо закључити да резултати треће групе такође указују на значајан утицај инпута. У Табели 4. приказаћемо појединачна постигнућа свих студената треће групе, како експерименталне (ЕГ) тако и контролне групе (КГ). 


\begin{tabular}{llll}
\hline & $\begin{array}{l}\text { Иницијална } \\
\text { постигнућа }\end{array}$ & Финална постигнућа & Разлика \\
\hline ЕГ1 & $76,8 \%$ & $84,9 \%$ & $+8,1 \%$ \\
\hline ЕГ2 & $84,9 \%$ & $89,7 \%$ & $+4,8 \%$ \\
\hline КГ1 & $88,7 \%$ & $87 \%$ & $-1,7 \%$ \\
\hline КГ2 & $87,6 \%$ & $87 \%$ & $-0,6 \%$ \\
\hline КГ3 & $81,1 \%$ & $82,2 \%$ & $+1,1$ \\
\hline КГ4 & $79,5 \%$ & $79,5 \%$ & 0 \\
\hline КГ5 & $86 \%$ & $86 \%$ & 0 \\
\hline
\end{tabular}

Табела 4. Појединачна постигнућа студената

\section{4. Дискусија}

Иницијални резултати показали су претходно стечено знање из правописа и језика, а финални резултати међусобни однос између резултата иницијалног и финалног диктата. Добијени резултати су у даљој анализи били подвргнути поређењу са подацима из упитника и наменског дневника како би се дошло до закључка у којој мери је фактор инпута утицао на правописна постигнућа студената. Резултати недвосмислено указују на значај инпута у настави правописа. Инпут у периоду пре иницијалног диктата био је прецизан предиктор постигнућа. Код прве групе испитаника, студената код којих у дужем периоду бележимо скоро свакодневни инпут и ван факултета, дошли смо до закључка да су правописна постигнућа изузетно висока, без обзира на врсту инпута, са просеком од чак 97,4\% успешности на финалном диктату. У оквиру друге групе испитаника бележимо напредак од 4,2\% код експерименталне групе, тј. оних студената који су у периоду од четири недеље скоро свакодневно били изложени језику кроз читање и слушање аудио-књига, за разлику од контролне групе, код које бележимо благи пад. У оквиру треће групе смо такође добили резултате који указују на значај инпута. Експериментална група је напредовала за чак 6,4\%, док је контролна благо назадовала. Све горе наведено доводи нас до закључка да је фактор инпута знатно утицао на постигнућа студената на финалном диктату, и то у веома кратком временском периоду.

\section{5. ЗАКљУЧАК}

Циљ нашег рада је био да утврдимо да ли фактор инпута утиче на правописна постигнућа студената треће године руског језика на Филолошком 
факултету Универзитета у Београду. Студенти су били подељени у три групе према постигнућима ради добијања што прецизнијих показатеља. У раду су анализирани резултати иницијалног и финалног диктата, као и подаци из упитника и наменског дневника сваке групе појединачно, како бисмо добили одговор на постављени циљ истраживања и хипотезу. Резултати истраживања потврђују хипотезу да повећање инпута утиче на правописна постигнућа. Установљено је да повећање ваннаставног инпута кроз читање и/или слушање аудио-књига утиче на правописна постигнућа испитаника, као и да је инпут у периоду пре иницијалног диктата представљао прецизан предиктор студентских постигнућа. Можемо закључити да се правописна правила не могу примењивати у писаној продукцији без скоро свакодневног инпута у дужем периоду у континуитету, тј. да приликом усвајања правописних правила руског језика студенти филолошког профила морају бити изложени инпуту како би били у могућности да усвојено примењују у продукцији. Резултати истраживања би могли бити драгоцени и другим факултетима у земљи и иностранству који школују студенте филолошког профила, премда би било корисно увек узимати у обзир особености правописа конкретног језика.

\section{ЛИТЕРАТУРА}

Carroll, S. (1999). Putting input in its proper place. Second Language Research 15 (4): 337-388.

Chaudron, C. (1985). Intake: On models and methods for discovering learners' processing of input. Studies in Second Language Acquisition 7: 1-14.

Ellis, N. (1994). Consciousness in Second Language Learning: Psychological Perspectives on the Role of Conscious Processes in Vocabulary Acquisition. Aila Review 11: 37-56.

Gass, S. (1997). Input, Interaction, and the Second Language Learner. Mahwah, NJ: Lawrence Erlbaum.

Hu, M., Nation, I. S. P. (2000). Vocabulary density and reading comprehension. Reading in a Foreign Language 13 (1): 403-430.

Krashen, S. (1985). The Input Hypothesis: Issues and Implications. Harlow: Longman.

Krashen, S. (2004). The power of reading. Westport, CT: Heinemann and Libraries Unlimited. 
Krashen, S., Lee, S. Y., Lao, C. (2017). Comprehensible and Compelling: The Causes and Effects of Free Voluntary Reading. Santa Barbara: Libraries Unlimited.

Renandya, W. A., Jacobs, G. M., Krashen, S., Ong, C. H. M. (2019). The power of reading: Case histories of second and foreign language readers. Language and Language Teaching 8 (1): 10-14.

Stipančević, A. (2020). Sprachförderung durch extensives Lesen und Hören im universitären DaF-Unterricht. Методички видици 11: 151-167.

Гинич, Е., Айджанович, Н., Меденица, Л. (2020). Современное положение русского языка в высших учебных заведениях Сербии, у Положај словенских језика, књижевности и култура на универзитетима у свету. Округли сто Комисије за наставу словенских језика и књижевности Међународног комитета слависта, ур. Љ. Бајић, Ј. Гинић, Н. Станковић Шошо (Београд: Филолошки факултет Универзитета у Београду): 18-47 [Ginich, E., Aĭdzhanovich, N., Medenitsa, L. Sovremennoe polozhenie russkogo jazyka v vysshikh uchebnykh zavedeniijakh Serbii, u Položaj slovenskih jezika, književnosti $i$ kultura na univerzitetima u svetu. Okrugli sto Komisije za nastavu slovenskih jezika i književnosti Međunarodnog komiteta slavista, ur. Lj. Bajić, J. Ginić, N. Stanković Šošo (Beograd: Filološki fakultet Univerziteta u Beogradu): 18-47].

Luka Medenica, University of Belgrade

Faculty of Philology, Department of Slavic Studies

\section{THE INFLUENCE OF INPUT ON ORTHOGRAPHIC ACHIEVEMENT OF PHILOLOGY STUDENTS OF THE RUSSIAN LANGUAGE}

\section{Summary}

Studies dealing with the effects of input on second language learning achievements in both school and academic contexts attract considerable interest in many countries. However, in our opinion, the area has not been researched to its full potential in Serbia. Thus, this paper sets out to discover factors that influence the orthographic achievements of Russian language students. A total of thirty-three respondents took part in this research and they were all third-year students of the Faculty of Philology at the University of Belgrade. In an attempt to examine input as a factor that can improve students' orthographic achievements, we formed two student groups - the experimental and the control group, on the basis of their previous exposure to L2 and their results on the 
initial assessment test. Through the use of journals that students kept in order to track their progress in the four-week-long period between the initial and the final test, which took place in December 2020, we were able to acquire data on respondents' input during this time frame. Students in the experimental group had the task to read and/or listen to Russian books of their choice every day during the aforementioned period. In contrast, students in the control group experienced no increase in extracurricular input during the same interval. Instructional input remained the same for all respondents. The initial and final testing results were compared to evaluate the role of the input factor in students' orthographic achievements. The research findings indicate that students in the experimental group made substantial progress. And our work further suggests that extended exposure to extracurricular input, gained through reading and/or listening to audiobooks, impacts the orthographic achievement of respondents. Finally, our result has led us to conclude that input in the period preceding the initial testing offered compelling signals for predicting students' achievement.

Key words: input, Russian as a foreign language, orthographic achievement, Faculty of Philology.

Примљено: 22. 1. 2021.

Прихваћено: 8. 7. 2021. 
